\title{
ISLAM AND THE STATE IN THE INDONESIAN EXPERIENCE
}

\author{
Bahtiar Effendy*
}

\begin{abstract}
This article analyses the source and nature of Islam-state relations, and the efforts made to find a viable synthesis between them. Like many other Muslim countries, Indonesia encountered difficulties in the attempt to establish a synthesis between Islamic political thought and the notion of a secular state. The author makes an important yet often neglected observation, that not all Indonesian Muslims support the politicisation of Islam and that the level and magnitude of support for ideological and symbolical Islam is relatively low in Indonesia. In order to find a middle way for the Indonesian setting in the post-Soeharto period, he argues in favour of a 'partial accommodation' of moderate Muslim concerns as a viable option for a more enduring relationship between Islam and the state.
\end{abstract}

\section{Introduction}

The issue of Islam-state relations still captures the attention of many students of the Muslim world. Being the largest Muslim country, and yet located far from the Islamic heartland, Indonesia provides an interesting context where the problem of the relationship between Islam and the state could be examined differently - though at some points similarities will always exist. In the past, theoretical discourse over this issue used to evolve around the question of whether or not Islam is in accord with a modern political system, with the idea of the nation-state as its major element. In the last ten years or so, attention to this issue has shifted towards the debate assessing the compatibility of Islam with democracy. Of course, regardless of preference, one cannot ignore the position of Islamic law (shari 'ah) in the discussion, that is to say, putting the issue in the light of Islam vis-à-vis modern political systems or Islam vis-à-vis democracy.

In Indonesia, the relationship between Islam and the state has a very long tradition. Its 'genealogical' roots reach back to the late thirteenth or early fourteenth century - a period in which Islam was introduced and spread in the archipelago. It was in the subsequent historical discourse, defining a meaningful dialogue with local socio-

* Bahtiar Effendy is Professor of Politics at Syarif Hidayatullah State Islamic University, Jakarta. 
cultural and political realities, that Islam became involved in politics as well as in the affairs of the state. In fact, throughout its development in Indonesia, Islam has become an integral part of the country's political history. But it was not until after the crumbling of colonialism - both Dutch and Japanese - in the mid twentieth century that the issue of the Islam-state relationship emerged in its most structured form.

Like many other Muslim countries, Indonesia experienced difficulties in the attempt to establish an easy synthesis between Islamic political movements and ideas and the state. In this country, the political relationship between Islam and the state had been characterised by severe tensions, if not hostilities. The regimes of both presidents Soekarno and Soeharto regarded Muslim activists as well as political parties based on Islam as potential power contenders capable of undermining the nationalist basis of the state. Primarily because of this, they worked hard to contain and domesticate them. As a result, not only did the leaders and activists of political Islam fail to make Islam the state ideology and religion in 1945 (during the Investigatory Committee for the Efforts for the Preparation of Indonesian Independence - the BPUPKI meeting) and again in the 1950s (during the Constituent Assembly debates over Indonesia's constitutional future), but they also found themselves repeatedly labelled 'minorities' or 'outsiders'. ${ }^{1}$ In short, political Islam had been constitutionally, physically, electorally, bureaucratically, and symbolically defeated. ${ }^{2}$ Most distressing, political Islam had frequently been a target of distrust, suspected of being opposed to the state ideology Pancasila.

For their part, politically active Muslims had looked on the state with suspicion. In spite of the willingness of the state to recognise and assist Muslims in the practice of their religious rituals, they considered the state as manoeuvring to dethrone the political significance of Islam and embrace the idea of a secular polity. In fact, this situation had often been treated as an indication that the state was applying a dual policy on Islam - something that was put into effect by the Dutch colonial administration. That is, while allowing the ritual dimension of Islam to flourish, it provided neither chances nor opportunity for political Islam to develop. ${ }^{3}$ In this respect, suffice it to say that a mutual suspicion between Islam and the state had occurred in a country in which the majority of its people (90 per cent) were Muslims. ${ }^{4}$

It is important to note, however, that over the years the degree and intensity of the suspicion and tensions varied from time to time. There were periods when the political relationship between Islam and the state was relaxed and cordial. In a time when issues related to ideology, politics, or the shari 'ah were brought to the surface they did function as windows of opportunity that reopened the old stigmatic enmity and hostility between Islam and the state.

With President Soeharto's departure from office in May 1998 things began to change. This included the mode of the relationship between Islam and the state. More than anything else, democracy has greatly reduced the overt enmity or hostility 
between Islam and the state as well as the mutual suspicion between the former's activists and the latter's administrators. This is not to say, however, that the problem of Islam-state relations no longer exists. On the contrary, it remains one key issue that consumes our energy as a nation to solve, especially with regard to the position of the shari 'ah in the state which is neither theocratic nor secular. However, such issues are now debated fairly and squarely in parliament as well as by the public at large.

This article attempts to analyse the source and nature of, and efforts to ultimately solve, the issue of Islam-state relations. While it may not bring fundamentally new insights, the article is intended to give the reader a firm foundation in the issues involved.

\section{Source of Contention: Theological Dimension}

It may not be sufficient to identify the shari ${ }^{-} a h$ as the source of contention with regard to the strained relationship between Islam and the state. Yet one could not forget the fact that the ideological debates that took place in the BPUPKI and the Constituent Assembly were the hallmark of the ideologically - or perhaps theologically - strained relationship between Islam and the state in Indonesia. In this context, one way to understand the crux of the problem with regard to the antagonistic nature of the relationship between Islam and the state lies in how religion is to be construed. As suggested by Robert N. Bellah, "the resurgence of Qur'anic Islam in the last century has contributed greatly to the emergence of the collective consciousness of the Muslim peoples, to what Karl Deutsch would call their "social mobilization"'. ${ }^{5}$ The limitations inherent in this process do not derive chiefly from the problem of converting Muslim consciousness into national loyalty, or from unrealistic attempts to implement detailed prescriptions of the sharī $a h$. The limitation comes rather from the power of veto that Islamic consciousness continues to exercise over the whole realms of political ideology and action. Of course, this may not be entirely a bad thing. It perhaps helps to restrain totalitarian tendencies. But it is also related to the tendency in many Muslim lands to rely on what Soedjatmoko calls "virtual images", rhetorical devices as a substitute for any serious and thorough programme of political reform. ${ }^{6}$

Complementing Bellah, it can be suggested that Muslims (and non-Muslims alike) generally believe in the holistic nature of Islam. As a divine instrument to understand the world, it is often conceived as more than a religion. Many have suggested that it can also be perceived as a "civil society", "a complete civilisation" and in fact a combination of both "religion and the state". ${ }^{8}$ What lies behind these formulations is actually a widely held notion that Islam constitutes more than its 
theological and/or ritual systems. Moreover, Islam does not recognise the wall of separation between the spiritual and the temporal.

While such perceptions remain largely unanimous, articulating it is quite problematic. This is not necessarily because of the different degrees of devotion among Muslims, but primarily because of the general character of the vast majority of Islamic doctrines, which allow multiple interpretations depending on the historical circumstances. As previously implied, there are those who are inclined to understand the holistic nature of Islam in an organic way - in the sense that the relationship between Islam and all aspects of life should be established in a legal/formal manner. Others prefer to interpret the holistic nature of Islam in a more substantive fashion, in which essence rather than form serves as the core orientation in social life. Failure to reconcile these conflicting views, as experienced by a large number of Muslim countries, has resulted in the development of an uneasy synthesis between Islam and the state in terms of their political relationships. This has generally been followed by the state's deliberate attempts to contain the religion's political idealism and activism which is perceived as threatening to national unity.

\section{Source of Contention: Political Dimension}

Modern Indonesia's Islamic political discourse has not escaped from such a predicament. Its genesis can be traced back to the early years of the country's nationalist movement, where the political elite engaged in the debates concerning the role of Islam in an independent Indonesian state. This search for a viable political relationship between Islam and the state continued well into the independence and post-revolutionary period, where a sizeable portion of Islamic political thinkers and activists called for the union between Islam and the state, manifested in the adoption of Pancasila as the basis of the state. To no avail, this ideological discourse, in turn, led to the development of a greater political animosity between Islam and the state, especially during the first 20 years of the New Order period - from the late 1960s until the late 1980 s.

If anyone cares to revisit the venture of the country's political Islam during the Revolutionary (mid 1940s), Liberal Democratic (mid 1950s), and early New Order (late 1960s) periods, he or she will see that the formalistic or legalistic articulations of Islam, especially in terms of its political idealism and activism, played a crucial role in the evolution of a highly strained relationship between Islam and the state. In those years, the ideological aura of political Islam was at the height of its intensity, demanding, among other things, that Islam be adopted as the state ideology or religion, along with its socio-political ramifications.

It is important to note, however, that Indonesian Islamic legalism and formalism did not evolve out of a vacuum. To a large extent, these thoughts and actions were 
driven by negative encounters with the West, most notably Dutch colonialism. There was no doubt that this long and penetrating process of colonial control had a devastating impact. For the large part of the Muslim community, this was particularly evident in the obstruction of their economic, educational, and political opportunities. This, in turn, contributed to the limited availability of choices for political Muslims to express their self-realisation in modern Indonesia. Thus, like Jamāl al-Dīn al-Afghānī (1838-1897) in Egypt and elsewhere in the Middle East, who waged an ideological-political campaign of pan-Islamism in the wake of the European encroachment, they inwardly sought refuge in the holistic nature of Islam for the purpose of countering Westernisation.

Not all Indonesian Muslims supported this kind of politics. A large and powerful group of Indonesian political thinkers and activists, concerned mainly with the nature of Indonesia's nation-state, rejected these ideas and worked hard to contain them in the 1950s. The relative success of this politics of containment left political Islam an outsider in the country's political process. Later, especially during the first 20 years of the New Order regime, political Islam had in fact become a principal target of ideological-political distrust and the state's exclusionary policies, because it was suspected, as I have already stated, of being inherently against the state ideology of Pancasila.

\section{New Intellectualism: In Search of a Way Out}

It is this kind of dismal situation that the new generation of Muslim thinkers and activists, emerging in the early 1970 s, intended to address. Their primary purpose has been to transform the earlier outlook of political Islam, from formal-legalism to substantialism. With their pioneering moves, political Islam seemed to have found a new format. This new thrust does not require a legalistic or formalistic connection between Islam and the state (or politics in general). As long as the state, ideologically as well as politically, operates on a value system which does not contradict Islamic teachings, it is sufficient for political Muslims to render their loyalty and support. This makes them at ease with Pancasila which, as they themselves suggest, is in accord with Islamic precepts.

In the late 1980s to mid 1990s, this integrative approach showed some encouraging signs of success. Political Islam seemed to have found ways to integrate itself into the discourse of Indonesia's national politics. In addition, there were also a number of indications which suggested that the state began to see political Islam not as a threat but as a complementary force in the country's national development.

Evidence of this new development has been the political relaxation of the state toward Islam, signified by the former's implementation of a number of policies perceived as being in accord with the latter's socio-cultural and political interests. 
Included in these accommodative actions were the passing of education law and religious court law; the compilation of Islamic law; the issuance of a joint-ministerial decision concerning the agency, Bazis, entrusted with the collection and distribution of zakāt or 'obligatory alms tax' (one of the 'five pillars' of Islam); the reversal of a long-standing policy which prohibited Muslim female high school students from wearing the headscarf and 'modest dress' (hijäb); the establishment of an Islamic bank; the annulment of the national lottery; and many others. ${ }^{9}$

\section{Post-Soeharto Indonesia: The Battle Continues}

However, has the transformation - from formalism to substantialism - been a genuine one? Indonesia's post-authoritarian political development tends to suggest otherwise. The political relaxation and liberalisation which allowed the unravelling of Soeharto's regime, has provided very fertile ground for political symbolism and legalism - not exclusively Islamic - to re-emerge. The birth of a large number of Islamic political parties has been the obvious sign of this new development.

There is no single explanation for these events. But, in a nutshell, they can be attributed to a simple fact that not every idealism and activism can be controlled or transformed into something else that others desire. Moreover, it is important to realise that the process of transformation occurred in a situation in which the politics of uniformity was the only game in town. In such a hegemonic atmosphere, how can anyone expect a clear or simple result?

President Soeharto's resignation bore tremendous and far reaching impacts. For one thing, it generated changes. Undoubtedly it has opened up the country's political 'Pandora's box'. For so many years, Indonesian politics had been too sacred a field for the society to be involved in. Politics had not been permitted to be played out competitively. Rather, it had become a luxurious arena enjoyed primarily by some sort of 'praetorian guard'. As a result, not only did society become more and more depoliticised - in the sense that it could not develop any political ideas and practices other than those dictated by the state - but it often faced confrontation and discouragement to the point where the realm of politics simply had to be avoided.

The resignation of Soeharto overturned the above situation. Public euphoria was everywhere, and as such demystified the sacredness or remoteness of politics. Thus, quite suddenly, politics became a public sphere where everybody felt they owned the very right to be involved in it. Waged under the spirit of reformation the public engaged in political activities with virtually no structural or socio-cultural barriers.

One of the most conspicuous indications of this political relaxation or liberalisation was the emergence of an astonishing number of political parties. Between May and October 1998, in the midst of socio-economic and political uncertainties - signified among other things by economic collapse, bloodshed, and enormous 
destruction in a number of big cities - Indonesia witnessed the birth of 181 political parties. Out of that number, 42 parties can be categorised as Islamic - the majority of which use Islam as their symbol and/or ideological basis. ${ }^{10}$

The (re)emergence of Islamic political parties is a phenomenon one could not fail to notice in Indonesia's turbulent years of reformation in the late 1990s. In fact, other than political relaxation and liberalisation, which appear to be the crux of the general tone of post-Soeharto Indonesia, one could say that the (re)birth of Islamic political parties is the most conspicuous feature of the reformation era-particularly if viewed from the Islamic group perspective. The formation of 42 Islamic political parties in a six-month period (May to October 1998), following the resignation of Soeharto, is too obvious an indication of the rising tide of political Islam. More importantly, it is also perceived as a sign of the resurgence of symbolical and ideological Islam along with the possible ramifications of this.

This phenomenon has brought about some speculation. But the tendency has been to see this development as déjà $v u$ - a recurrent attempt on the part of many Muslim political thinkers and activists to (re)politicise Islam or (re)assert Islamic interests in politics. At least, if the term 'politicisation of Islam' sounds pejorative, the resurgence of Islamic parties has been viewed as an indicator that for (many) Muslims - and perhaps for (many) other political practitioners as well - Islam can function as a political resource. Though it is justifiable in a free society - in fact it is often considered as a natural right - nonetheless the formation of political parties based on Islam will always remind the public - non-Muslims in particular - of the historical stigma of bringing Islam to the forefront of Indonesian politics. As such it will always be perceived as an attempt to legally or constitutionally link Islam with politics or to establish a state based on Islamic principles.

However, the alarmism did not come only from non-Muslim quarters. Some Muslim circles too voiced a similar apprehension for different reasons. Kuntowijoyo, a highly respected Yogyakarta-based Muslim intellectual, wrote a provocative essay outlining six arguments why Islamic political parties should not be formed. Like many Muslims, he recognises that during Soeharto's 32 years in power, Islam was politically marginalised in the sense that Muslim political activists could not express thoughts and actions other than those allowed by the state. Accordingly, only those who shared - and felt comfortable with - the New Order's socio-economic and political agenda, which emphasised stability and order, could participate in politics.

In spite of this, in the view of Kuntowijoyo, the New Order's politics of marginalisation was a blessing in disguise. In a situation in which politics was a forbidden realm for many Muslims, the santri community had managed to diversify the political meaning of Islam by deliberately focusing their potential and energy on areas of strategic interest such as human resource development. The Muslim 
intellectual boom, which Nurcholish Madjid epitomised in Indonesian Islam in the mid 1980s and early 1990s, was a direct result of that choice. ${ }^{11}$

No less important was the fact that Muslims' involuntary retreat from politics in those years brought about major impacts on at least two important socio-religious phenomena. First, it played a pivotal role in establishing a relatively amicable relationship between Muhammadiyah and Nahdlatul Ulama (NU). Any student of Indonesian political Islam could not fail to notice that these two organisations shared irreconcilable theologico-political differences, which affected the nature of the relationship between these two socio-religious leviathans. During the height of the venture of Indonesian political Islam of the 1950s and early 1960s, whatever differences Muhammadiyah and NU had could easily be transformed into socioreligious and political conflicts.

Second, it contributed to the making of a religio-political convergence between the santri and abangan communities. The dichotomy between santri and abangan had been associated mainly with differences in religious understanding as well as the application of Islamic tenets in the daily life of Javanese Muslims. Given the position of Islam in Indonesian politics, this santri-abangan socio-religious grouping spilled over into the realm of politics. In fact, it polarised the country's modern politics into two major cleavages or currents (aliran). While the santris were inclined to direct their political orientations toward Islamic political parties, the abangans were more apt to express their political associations within the nationalist or communist parties. ${ }^{12}$

This kind of interplay between religion and politics characterised and sharpened the schism between these two religio-cultural groupings. However, the absence of aliran politics in Soeharto's New Order administration enabled santri and abangan communities to converge religiously as well as politically. More importantly, it allowed Muslims to build a larger umbrella for the Islamic community under which religiosity was not measured by certain political ideas or ideological and party affiliations, but simply by exercising religious tenets.

Given the above perspectives, for Kuntowijoyo, the re-entrance of Islam into politics could jeopardise this favourable development. In his view, the establishment of political parties based on Islam would be likely to

- stop Muslim social mobility;

- bring about disintegration within the Muslim community;

- encourage Muslims to become myopic, emphasising more short-term (political) objectives;

- narrow Muslims' understanding of Islam;

- cease the proliferation of key Muslim figures; and

- alienate the younger Muslim generation. ${ }^{13}$ 
Kuntowijoyo is correct in suggesting that the establishment of an Islamic party may bring about certain implications not necessarily consistent or compatible with some of the achievements Muslims have already accomplished when they concentrated their potential and energies on issues related to non-political aspects of Islam. Nevertheless, many Muslims do not seem to share his opinion. In fact, not only did they found Islamic parties, but they created Islamic political institutions in large numbers, unprecedented in the history of the Muslim world. The existence of 42 Islamic parties is indeed a clear challenge to his view.

His alarmism is well taken in so far as it is placed in the context of the pre-New Order circumstances in which Islamic political ideas and practices were generally perceived to be legalistic and formalistic in character. There is no doubt that the development of the new Islamic intellectualism and activism in the past three decades has contributed to the transformation of a sizeable proportion of Muslim intellectuals and practitioners to adhere to a more tolerant and inclusive Islam. Even so, many believe that some Muslims still aspire to a certain political idealism and symbolism - such as the use of Islam as a party platform and identity. However, it is a mistake to assume that this is an indication that Muslim political thinkers and activists will always "orient Indonesia to the direction of Mecca". ${ }^{14}$ This viewpoint is only true in a certain historical terrain, such as in the 1950s or early 1960s, when the relationship between Islam and politics not only contributed to the birth of aliran politics, but also polarised the Muslim community into santri and abangan socio-religious groupings. Thus, arguing that using Islam as a party platform and identity is automatically identical to promoting the idea of Islam as the basis of the state requires a number of factors rather than simply relying on a stigmatic account of history.

Nevertheless, it is important to note that in so far as this issue is concerned (i.e. the relationship between Islam and politics), historical stigma - more than anything else - is still the primary popular basis of perception. Because of that, Kuntowijoyo is not alone in trying to convince or alarm the public into believing that the foundation of Islamic parties could eventually resurrect the past - the (re)emergence of an antagonistic and polarised Muslim community with all the possible ramifications of this. Even Amien Rais - an important disciple of Mohammad Natsir - shares a similar notion of automaticity that "if religious idioms and symbols are used to increase political support, religion will become a divisive issue among Muslims and sensitive, possibly non-negotiable principles and beliefs will burden electoral politics". ${ }^{15}$ Partly because of such a conviction, he chose to form a religiously neutral party such as PAN, rather than an Islamic one.

If the use of Islam as a party platform and identity is not meant to entertain the idea of Islam as the basis of state, why then do some Muslim political practitioners remain committed to the idea of Islamic symbolism in politics? Furthermore, what 
are the most likely explanations for those who are still inclined to see the current emergence of Islamic symbolism in politics in light of the past? To answer these questions, one has to examine first the dynamics of the relationship between Islam and the state, and secondly the political relaxation and liberalisation which the fall of Soeharto had brought about.

Recalling the previous discussion, it is safe to say that finding a proper place for Islam - or any religion for that matter - in Indonesia's socio-cultural, economic, and political development is the crucial point in the whole construct of the relationship between Islam and the state. The earlier generation of Islamic political thinkers and activists were of the opinion that Islam should function as the constitutional and legal basis of the state. Not every Muslim, however, agreed to the idea that organically linked Islam with the state. Instead, they proposed the notion of a 'deconfessionalised' state based on the ideology of Pancasila. This made Indonesia neither Islamic nor secular, but a "religious" state, in the sense that the state allowed and assisted its citizens to perform their religious obligations. ${ }^{16}$

The idea of a 'deconfessionalised' state may have been a viable compromise between the religious and the nationalist groups. However, the manner in which Pancasila as well as the 1945 constitution were formulated, introduced, debated, and finally accepted as the two most important legal bases of the state seemed to have left the impression that the adoption was temporary in nature. At best, the acceptance was not based on genuine compromises, as pressure and fait accompli were part of the environment of the constitutional committee meetings. In this case, as the records of the minutes of BPUPKI ${ }^{17}$ indicate, Soekarno repeatedly asked members of the committee, especially those from the Islamic circle, to immediately accept Pancasila and the 1945 constitution if they really wanted independence to occur. In the view of Soekarno, a complete and revised version of the ideological as well as constitutional arrangement of the state could be formulated at a time when the country was independent.

Partly because of this, Muslims as well as other political forces debated the issue once again in the Constituent Assembly. The formation of the Constituent Assembly following the first general elections of 1955, with the sole duty to formulate the ideological and constitutional basis of the state, reasserted the temporary nature of Pancasila and the 1945 constitution. The fact that all four Islamic parties Masyumi, NU, PSII, and Perti - reintroduced Islam as the basis of the state was only an exercise of their constitutional duties based on their religious as well as political aspirations, which they perceived to be appropriate and necessary. As such, one should not argue that Muslim parties were absolutist with regard to their religio-political ambitions. Like their nationalist counterparts, Muslims expected to have meaningful discussions and be able to reach a viable compromise. Indeed, they had done so in respect to their duty to formulate a much better constitution - 
with the exception of the question of the state ideology (i.e. Pancasila or Islam). The fact that Soekarno, backed by the military at that time, did not wish to go the extra mile to enable a genuine compromise to take place, and chose instead to issue a presidential decree in June 1959, which abrogated the laborious work of the Constituent Assembly - thus putting Pancasila and the 1945 constitution once again into effect - only proved that a truly negotiated settlement among the country's national elite on the two most important issues (i.e. Pancasila and the 1945 constitution) failed to occur. ${ }^{18}$

This remained the case for the next 49 years. Forces that contributed to the failure of the national elite to compromise on issues related to the socio-cultural, economic, and political life of the country became more apparent during Soekarno's seven years and Soeharto's 32 years of rule. Especially during Soeharto's rule, the ideological position of Pancasila and the 1945 constitution was strengthened and reasserted. They were treated as the two most sacred documents, which no one could discuss, question, and interpret in any way other than what was dictated by the state. Complementary to this situation, political or ideological Islam was severely contained, leaving it as an outsider in the country's political dynamic. During the first 20 years of the New Order administration, political Islam became a principal target of the state's exclusionary politics as well as the focus of ideological and political distrust. More particularly, political Islam was suspected of being inherently against the state ideology of Pancasila.

This was indeed a distressing situation. As stated above, the new generation of Muslim political thinkers and activists that emerged from the 1970s onwards, endeavoured to reverse the situation by adhering to more substantive socio-political ideas of Islam. They did not aspire to the notion of Islam as the basis of the state. In their view, as long as the state operated on a value system that did not contradict Islamic teachings, there was no religious obligation to question the existence of such a state. More importantly, they also believed that in essence, Pancasila was in accord with Islamic precepts.

By the late 1980s, a meaningful transformation with regard to Islamic political ideas and practices began to evolve. Muslims seemed to be at ease with the idea that Indonesia is neither an Islamic nor a secular state. When the state reversed its treatment of Islam, leaning to a more accommodative stance toward Islamic aspirations, the hostility was substantially reduced. In a situation like this, there was no religio-political need to raise the question of Islam as the basis of the state.

One important question still remains, however. How genuine was the transformation of Islamic political ideas and practices? Or rather, how sincere was the accommodative response of the state toward Islam? In a situation in which the state was very much still exclusionary in nature, there was no way of knowing the degree of sincerity of both sides - the Muslims and the New Order state. This issue 
needs to be raised because of the view that, as mentioned earlier in this article, the hegemonic and authoritarian nature of the state was the major weakness of the whole process of Islamic ideological and political transformation. The fact that the state contained political Islam did not actually leave much choice for political Islam to pick in order to survive. Strong as it was, no single socio-cultural, economic, and political institutions could escape the web of influence of the New Order state.

Because of that, it is fair to suggest that there was always a dimension of religiopolitical expediency. To be sure, there were Muslims who - for religious or other reasons - believed that Islam does not oblige its adherents to form a theocratic state. And the process of the transformation of Islamic political ideas and practices during the New Order administration strengthened this conviction, and increased the number of those who shared and supported such a viewpoint. Nonetheless, it was equally true that not every Muslim was on the same wagon of Islamic intellectual transformation. There were those who saw the issue differently - tacitly or otherwise conserving an organic view of Islam-state relationship. It was the nature of the New Order state which prevented many of them from voicing and developing their genuine Islamic political aspirations.

While the proper relationship between Islam and the state remains a debatable issue among Muslims, this was not the case with regards to the characteristics of the New Order state. Muslims generally believe that the New Order state was basically hegemonic, practising non-competitive politics, and leaving no space for the public to articulate their demands. Indeed, it was considered a 'repressive-developmentalist' institution. When the pillars that had supported Soeharto's way of governing crumbled, quite a sudden opportunity to embrace long-overdue ideological and political aspirations emerged. Like many other political practitioners, politically active Muslims wanted to express their own ideas which differed from what was decreed by the state - an exclusionary political system; the existence of two docile parties (PPP and PDI) and one corporatist political institution (Golkar); and the adoption of Pancasila as the sole ideological basis of existing socio-religious and political organisations. The rise of Islamic political parties - like many other political parties - and the adoption of Islam - like many other ideologies - as party ideology and symbol should be viewed from this perspective. ${ }^{19}$

Thus, the political relaxation and liberalisation, which Soeharto's sudden departure from power brought about, was the major factor in the emergence of political forces and the articulation of their own interests. With virtually no socio-cultural, political, and ideological barriers in the way, they were very much on their own course of action and determination. Therefore, it is only a natural phenomenon that political Islam has re-emerged and adopted Islam as its party ideology, symbol, and platform. As suggested by Nurcholish Madjid, "We have lost our freedom for more than 30 years. All of a sudden, the freedom is back in our hands, which of course makes us 
happy. From this perspective, creating a large number of parties is only a natural phenomenon. This is like children who just got new toys." ${ }^{20}$

The fact that such a development has aroused apprehension and alarmism - not only from non-Muslim quarters, but also from many Muslims as well - is equally understandable. As in the past (1950s), democracy gave ample opportunity for Muslims to aggregate and articulate their interests. Ironically, it was in this liberal and democratic situation that the debates on the question of Islam as the basis of the state reached their height. The failure to seek compromises, especially with regard to the position of Islam in Indonesia's political and ideological construct, brought about certain historical stigma. Primarily because of that stigma, the birth of 42 Islamic political parties was conceived in a manner in which modern Indonesian political history had evolved. And because of that stigma, the existence of Islamic political parties will always be associated with the idea of a theocratic state and/or the absorption of the shari' ah into the country's legal system.

This stigmatic standpoint, however, does not seem to provide an accurate description of the characteristics and agendas of post-Soeharto era Islamic political parties. The inclination to generalise all Islamic parties as proponents of Islam as the basis of the state is clearly misleading. The newly formed Islamic political parties cannot be viewed as homogeneous entities. Monolithicism is certainly not a useful concept to apply in this case. This is especially true given the fact that not every Islamic political party uses Islam as their ideological basis. While Islamic nuances and fervour are undoubtedly present, even in the self-claimed nationalist parties such as PKB (with NU members as its core constituents and Islamic jurisprudence as the basis of the party platform) and PAN (with Muhammadiyah members as its only meaningful supporters), some took Pancasila - or a combination of Pancasila, Islam, and the 1945 constitution - as their party basis.

If party basis can be regarded as party ideology, the reality presented above is surely a strong indication that not all Islamic parties adhere to a single ideological orientation. Should this characteristic stand, it is equally true that not every existing Islamic party adopts a single, unified political aspiration. On the contrary, they seem to have different - often contradictory - political agendas. Other than the fact that all ten Islamic parties which gained one or more seats in the parliament - together enjoying 172 seats - agreed with Amien Rais to form an 'Islamic' or 'Central Axis' caucus with the sole purpose at making Abdurrahman Wahid Indonesia's fourth president, there were hardly any other primordial aspirations shared by the existing Islamic parties. Even such important issues as whether or not Article 29 of the constitution should be amended - a process which opened up the possibility of inserting the Jakarta Charter into the constitution - was not able to bring Muslim political thinkers and activists into a single line, whereas in fact it was often considered of great importance to Muslim interests. 
When the process to amend the constitution began in 1999, it was clear from the start that not all Islamic parties shared the same vision regarding the proper place of Islam in the state. This situation continued well until 2002, the year in which parliament was scheduled to complete their work to amend the constitution. Throughout the process, Islamic political forces demonstrated the fact that they have different opinions concerning the matter. There were those who wanted to revive the Jakarta Charter and insert it into the constitution, which would make the implementation of the shari 'ah, in the eye of the state, mandatory for all Muslims. Others, while not necessarily against the idea of putting some Islamic precepts into the country's legal system, rejected that particular idea quite explicitly.

Given the existence of public apprehension and alarmism toward political Islam, it is interesting to note that the support for inserting the Jakarta Charter into the constitution was minimal. Out of the ten Islamic parties in the parliament, only PPP, PBB, and PDU - together occupying 87 seats - supported the inclusion of the Jakarta Charter in the new constitution. Of course, these three parties had done their best to realise their objectives. Nonetheless, they did not seem to launch a political struggle in a manner in which their predecessors did half a century ago in the Constituent Assembly debates. Although the likelihood is that these three Islamic parties would continue their efforts to have the Jakarta Charter included in the constitution, they did not block the assembly decision to stick to the original formulation of Article 29 of the constitution - which reads that the state is based on one God. The fact that the process to amend the constitution was far from deadlocked, especially on issues related to the relationship between Islam and the state, is an indication that the historical stigma of the ideological debates that occurred in the mid 1940s and the late 1950 s can no longer be employed as a reference point in analysing the existing Islamic political parties in post-Soeharto Indonesia.

As far as the idea of placing Islam in its appropriate position within the state is concerned, it is also important to note that unlike their struggle in the mid 1940s and 1950s, current Islamic parties do not aspire to Islam as the basis of the state. Unlike before, no single Islamic party has ever publicly proposed the idea of Islam as the basis of state. At best, as already mentioned, their aspirations have been reduced or modified to something like the revival of the Jakarta Charter. Coupled with the fact that the process of constitutional amendment did not end in deadlock, it is safe to argue that the religio-political circumstances have undoubtedly changed. Putting that in perspective, there is no legitimate reason for seeing the rebirth of Islamic political parties in light of the past. Given what has evolved over the last 50 years or so, one should not expect that a perfect and complete transformation from Islamic political legalism and formalism to substantialism can ever occur. However, the fact that Islamic parties are by no means homogeneous is evidence that their emergence should not and cannot be perceived in a monolithic manner. ${ }^{21}$ 
However, it is not only the emergence of Islamic political parties that has created apprehension and alarmism. Besides what has been suggested, the New Order's departure was also followed by the rise of a number of Islamic organisations. Apparently, the opening of this Pandora's box did not only encourage the development of political parties, but also the emergence of various socio-religious organisations. In a situation in which politics seems to be the only game in town, these organisations regarded themselves as instruments to express and channel Islamic aspirations. In fact, more than the existing Islamic parties, they often articulated their interests in a strong and forceful way which made others see them in light of radicalism. This is especially true with respect to their calls for sharī $a h$ implementation.

Thus, other than giving more weight to what has been addressed by several Islamic political parties, their existence has been viewed as a confirmation of "the rising tide of Indonesian (political) Islam". ${ }^{22}$ Their blunt outlook and militant tendency in communicating Islam has led many to observe their resurgence in light of the past. The context of a globalised world has also encouraged them to relate this new development to the worldwide trend of political Islam. This is not to suggest that these religious organisations have connections with the international Islamic movement - though they might share comparable ideas and thoughts.

Unlike the Islamic parties, the birth of these organisations was not an immediate response to Indonesia's democratic transition. Instead, their development was more a reaction to the socio-religious and political circumstances which evolved during the period of transition, which in their view did not seem in accord with Islamic values or Muslim interests. The inability of the state to administer effectively and solve pressing problems that concerned the lives of many Muslims (e.g. socio-religious conflicts, law enforcement on gambling and prostitution, regulation of alcoholic beverages, etc.) has triggered the emergence of these Islamic groups. Similarly, the United States foreign policy towards the Islamic world, which is often perceived as uneven-handed, discriminatory, and unjust, especially concerning the Palestinian nation, has also contributed to their emergence. ${ }^{23}$

These Islamic organisations include, to name only the most prominent ones, Front Pembela Islam (Islamic Defenders Front); Forum Komunikasi Ahlus Sunnah Wal Jamaah (FKASWJ, Ahl al-Sunnah wa-'l-Jamā'ah Forum) along with its militia wing, Lasykar Jihad (Jihad Brigade); Majelis Mujahidin Indonesia (MMI, Indonesian Mujahidin Council) along with its Lasykar Mujahidin (Mujahidin Brigade); Hizbu al-Tahrir (Liberation Party); Hammas (Inter-Campus Muslim Students Association); Front Hizbullah (Hizbullah Front); Ikhwanul Muslimin; and the relatively much older organisation, Kisdi (Komite Indonesia untuk Solidaritas Dunia Islam, Indonesian Committee for Islamic World Solidarity).

All of these groups seem to share the same concern - i.e. that Islamic shari 'ah law should have been taken more seriously by the state as well as the greater 
Muslim society. Such a viewpoint is based primarily on three important factors - theological, demographic, and socio-political. The first factor emphasises the fact that Islam is perceived as a religion which offers guidance and solutions to all aspects of life - socio-cultural, economic, political and so forth. This position has led them to believe that all Muslims are religiously obliged to base all aspects of their lives on Islamic values and teachings as outlined in the shari' $a h$. The second factor refers to the fact that the majority of Indonesians are Muslims. Adherents of Islam constitute 87 per cent of the country's population. And for them, this fact alone should function as socio-cultural and political legitimacy for making Islam as the basis of the state - or at least to recognise the shari ${ }^{-} a h$ as a core ingredient or an integral part of the constitution. ${ }^{24}$ The last factor points to the fact that the secularpositive law has not brought about socio-cultural, economic, legal, and political improvements for Muslims. In their view, for more than half a century, Indonesia has been plagued with a number of socio-economic and political misfortunes - with the recent multidimensional crises as its pinnacle - for which only Islam can serve as the ultimate solution.

Should this be the case, then it is fair to argue that what these organisations aspire to is actually reminiscence to what had been articulated and aggregated by the Islamic groups in the 1940s and 1950s. This means that for more than half a century, Indonesia's national elite have not been able to come to terms with the position of Islam in this archipelagic nation state. As a result, the question of Islam - especially issues related to the implementation of the shari ${ }^{\prime} a h$ - has tended to become a recurrent issue. Unless a negotiated settlement can be reached, it will always re-emerge in various forms, depending on the situation.

\section{Towards a Partial Accommodation of Islam: Some Conclusions and Recommendations}

From what has been presented at length, it is difficult not to see the development of political Islam during the post-Soeharto period in light of legalism and formalism. The intellectual transformation which occurred between the 1970s and 1990s seemed to have lost its significance when ideological, symbolic, and formal Islam gave the impression of dominating the new discourse on Indonesia's political Islam. The use of Islam as a party basis, the call for the implementation of the shari' ah, the attempt to insert the Jakarta Charter into the new constitution, and opposition to Megawati's presidential candidacy in 1999, based on the religious argument that men are to lead (or be stronger than) women, are clear indicators of the rising tide of political Islamism.

In spite of this new development, one should not view it as a genuine phenomenon. In fact, the birth of 42 Islamic parties - like other parties - has to be seen from 
the perspective of the shifting pendulum of Indonesia's political system, from authoritarian to democratic rule. This means that one should always question whether or not such new developments are genuine or permanent in nature. At a time when transition seems to be characterised by some degrees of socio-economic and political fluidity - not to say breakdown - it is difficult to see things with certainty. The fact that only 20 Islamic parties met the electoral requirements in 1999 , and only ten gained one or more seat, suggests that this new development is primarily due to the euphoric and myopic nature of the transition, rather than to a well thought out and deliberated religio-political determination. When those who earlier opposed Megawati's presidential candidacy finally accepted her victory in her constitutional appointment to succeed Abdurrahman Wahid to become the country's fifth president, this only indicated that religious considerations are temporarily and not permanently upheld. Should religious principles become a determining factor in politics, any leadership posts contested by Megawati or any female candidates for that matter should have been rejected.

A similar viewpoint can also be used to understand the fact that PPP, PBB and PDU politicians, who fought for the insertion of the Jakarta Charter into the new constitution during the process of amendment, eventually gave up their cause and did not block moves to stick to the original formulation of Article 29, which says that the state is based on one God. They may have accepted their constitutional defeats on a temporary basis. However, the choice not to have the case settled by way of voting can also cast doubt on their religious convictions in politics. Therefore, unlike the earlier Muslim politicians in the Constituent Assembly who tackled the issue by way of vote - though neither sides of the spectrum received adequate support to win their cause - post-New Order Muslim politicians appear to have moderated themselves with regard to their efforts to articulate and aggregate Islamic interests.

What seems to be more certain is that the level and magnitude of support for ideological and symbolical Islam is relatively low and small. The majority of Muslims, as signified by the limited number of seats enjoyed by Islamic forces in the parliament and the rejection of the Jakarta Charter, remain moderate and aspire to a more viable and proper relationship between Islam and the state. This view is also shared by the two most important religious organisations in the country Muhammadiyah and NU. In light of Indonesia's political history, it is fair to say that

- in two democratic situations, legalist and formalist political Islam was unequivocally defeated. Its fate and destiny - to say the least - was even bleaker in an authoritarian political setting.

This is not to suggest, however, that the majority of Muslims (politicians) oppose the sharì $a h$. Being Muslim, they accept the significance of the sharì $a h$ and are 
obliged to implement Islamic teachings in all aspects of life. Yet they differ greatly with regard to how the shari ' $a h$ is to be understood, interpreted, and implemented. They do not believe that the shari 'ah should be adopted in its entirety and serve as the positive law of the land. Instead, they share the idea that certain elements of the sharì 'ah can be formulated into legally-binding law, such as on issues related to marriage and divorce, inheritance and endowment, zakāt collection and distribution, the pilgrimage, and the like. The fact that many Muslims feel that the state's accommodation of Islamic law is still limited has not stopped them from struggling within the bounds of the existing system, laws, and regulations. Having said this, it is safe to argue that:

- Partial accommodation seems to be a viable option for a more enduring relationship between Islam and the state. The commonly shared notion that Indonesia is neither a theocratic nor a secular state only suggests the importance of the obligatory nature of the state in accommodating the interests of Muslims.

- At the same time, realising the heterogeneity of Indonesia's socio-religious origins, it is the task of every Muslim to articulate and express their interests in so far as they do not disrupt the construct of the country's nation-state.

For more than half a century, Indonesia has been unable to conduct an uninterrupted dialogue concerning the proper role and position of religion in the state. In the 1940s and 1950s, the effort was hampered by a lack of time, and Soekarno's and the military's political manoeuvrings. Throughout the New Order government, the debate was forbidden because of the deep-seated suspicions of the state regarding its disruptive potentials. Taking into consideration all the lessons we have learned in the last 50 years or so, it is time for the national elite - religious as well as political - to undertake such an important dialogue in order to reach an appropriate settlement.

\section{Notes}

1. Ruth McVey, "Faith as the Outsider: Islam in Indonesian Politics", in: James Piscatori (ed.), Islam in the Political Process (Cambridge: Cambridge University Press, 1983), 199-225; W.F. Wertheim, "Indonesian Moslems under Sukarno and Suharto: Majority with Minority Mentality", in: B.B. Hering (ed.), Studies in Indonesian Islam (Townsville [Australia]: James Cook University of North Queensland, 1986).

2. Donald K. Emmerson, “Islam and Regime in Indonesia: Who's Coopting Whom?”, paper delivered at the 1989 annual meeting of the American Political Science Association (APSA), 31 August 1989.

3. Harry J. Benda, The Crescent and the Rising Sun (The Hague and Bandung: W. van Hoeve Ltd, 1958).

4. B.J. Boland, The Struggle of Islam in Modern Indonesia (The Hague: Martinus Nijhoff, 1971); Allan Samson, "Islam and Politics in Indonesia", PhD dissertation, University of California at Berkeley, 1972. 
5. Robert N. Bellah, Beyond Belief: Essays on Religion in a Post-Traditionalist World (Berkeley and Los Angeles: University of California Press, 1991).

6. Ibid.

7. H.A.R. Gibb (ed.), Whither Islam? (London: Victor Gollancz Ltd, 1932).

8. Mohammad Natsir, Islam sebagai dasar Negara (Bandung: Pimpinan Fraksi Masyumi dalam Konstituante, 1957); Abu A'la al-Maududi, The Islamic Law and Constitution (Lahore: Islamic Publication, 1977).

9. Bahtiar Effendy, Islam and the State in Indonesia (Singapore: Institute of Southeast Asian Studies, 2003).

10. Arskal Salim, Partai-partai Islam dan relasi agama-negara (Jakarta: Pusat Penilitian IAIN Jakarta, 1999).

11. Kuntowijoyo, "Enam alasan untuk tidak mendirikan parpol Islam", Republika [Jakarta], 18 July 1998.

12. Clifford Geertz, The Social History of an Indonesian Town (Cambridge MA: MIT, 1965).

13. Kuntowijoyo, "Enam alasan".

14. Emmerson, "Islam".

15. M. Amien Rais, "Islam and Politics in Contemporary Indonesia", in: Geoff Forrester (ed.), Post-Soeharto Indonesia: Renewal or Chaos? (Singapore: Institute of Southeast Asian Studies, 1999), 198-203.

16. C.A.O. van Nieuwenhuijze, "The Indonesian State and 'Deconfessionalized' Muslim Concepts", in: C.A.O. van Nieuwenhuijze, Aspects of Islam in Post-Colonial Indonesia: Five Essays (The Hague and Bandung: W. van Hoeve Ltd, 1958).

17. Toward the end of World War II, BPUPKI (Badan Penyelidik Usaha Persiapan Kemerdekaan Indonesia) was a Japanese-organised committee for granting independence to Indonesia.

18. Deliar Noer, Partai Islam di Pentas Nasional 1945-1965 (Jakarta: Pustaka Utama Grafiti, 1987); Ahmad Syafii Maarif, "Islam as the Basis of State", PhD dissertation, University of Chicago, 1983.

19. Bahtiar Effendy, (Re)politisasi Islam: Pernahkah Islam berhenti bepolitik? (Bandung: Mizan, 2000).

20. Republika [Jakarta], 7 June 1998.

21. Bahtiar Effendy, “Antara substansialisme dan formalisme", Panji Masyarakat [Jakarta?] 40 (2000).

22. "Van Zorge Report on Indonesia" 2, no. 20 (30 November 2000), available online at http://www. vzreport.com/main/about-us.html (accessed on 12 July 2010).

23. Penelitian radikalisme agama dan perubahan sosial di DKI Jakarta (Jakarta: Pusat Budaya dan Bahasa (PBB) dan Pemda DKI Jakarta, 2000).

24. Maarif, "Islam". 